\title{
PENGGUNAAN METODE IMPRESSED CURRENT CATHODIC PROTECTION (ICCP) DALAM PENCEGAHAN KOROSI PADA JALUR PIPA 24" SKG X PRABUMULIH BARAT - CAMBAI PT PERTAMINA EP ASSET 2 FIELD PRABUMULIH
}

\author{
Roni Alida ${ }^{1)}$, Budiono ${ }^{2)}$ \\ 1Program Studi Teknik Eksplorasi Produksi Migas Politeknik Akamigas Palembang, 30257, Indonesia \\ 2Program Studi Teknik Eksplorasi Produksi Migas Politeknik Akamigas Palembang, 30257, Indonesia
}

\begin{abstract}
Abstrak: Salah satu penyebab kerusakan pada sistem jaringan dan fasilitas pipa distribusi gas yaitu korosi. Untuk mencegah terjadinya korosi pada pipa flowline, PT Pertamina EP Asset 2 Field Prabumulih yang berada di SKG X Prabumulih Barat menggunakan sistem proteksi katodik. Proteksi Katodik (Cathodic Protection) adalah teknik yang digunakan untuk mengendalikan korosi pada permukaan logam dengan menjadikan permukaan logam tersebut sebagai katoda dari sel elektrokimia. Pada PT Pertamina EP Asset 2 Field Prabumulih digunakan sistem proteksi katodik arus tanding atau yang dikenal dengan ICCP (Impressed Current Cathodic Protection), dimana metode ini lebih efektif digunakan dari pada menggunakan metode anoda korban atau SACP (Sacrificial Anode Cathodic Protection). Proteksi katodik dianggap bekerja jika, potensial minimum adalah $850 \mathrm{mV}$, potensial maksimum adalah1.300 mV,range inilah yang dijadikan nilai oleh PT Pertamina EP Asset 2 Field Prabumulih terhadap pengukuran potensial pipanya untuk mencegah dari korosi. Umur pipa line SKG X-Cambai sendiri yaitu 40 tahun, maka dari itu pemilihan jenis anodanya harus mengikuti umur pipa tersebut supayalebihekonomisdanlebih efisien. Dalam perhitungan jumlah anoda, PT Pertamina EP Asset 2 Field Prabumulih menggunakan 1 pcs anoda untuk memproteksi jalur pipa seluas area 19,33 $\mathrm{m}^{2}$. Adapun parameter-parameter keberhasilan dalam pelaksanaan sistem proteksi katodik ini yaitu tegangan yang dihasilkan tidak melebihi range yang ditentukan, yaitu $850-1.300 \mathrm{mV}$ dan pipaterlindungi dari korosi.

Kata Kunci : Metode Proteksi Katodik, Korosi, Impressed Current Cathodic Protection
\end{abstract}

\section{PENDAHULUAN}

Pipa penyalur merupakan sarana penting dalam kegiatan perminyakan. Pipa digunakan untuk mengangkut minyak dan gas dari lapangan produksi ke konsumen akhir. Penggunaan pipa untuk transportasi minyak dan gas melalui jalur darat secara umum lebih ekonomis jika dibandingkan dengan penggunaan kereta pengangkut, kapal tanker atau transportasi lain. Selain lebih ekonomis, pengunaan pipa sebagai media penyalur juga lebih efisien dari segala kapasitas.

Sistem jaringan dan fasilitas pipa distribusi gas memiliki berbagai resiko kerusakan. Salah satu penyebab kerusakan pada sistem jaringan dan fasilitas pipa distribusi gas antara lain korosi. Untuk menjamin kelancaran operasional sistem jaringan dan fasilitas pipa distribusi gas, perlu dilakukan kontrol korosi terhadap semua sistem jaringan dan fasilitas pipa gas. Oleh karena itu, dilakukanlah metode proteksi pipa dengan menggunakan sistem proteksi. Sistem proteksi ini sangatlah penting digunakan untuk melindungi pipa dari korosi, karena dampak yang terjadi yang disebabkan korosi sangat merugikan. Jadi sistem proteksi sangat cocok digunakan dalam menghambat laju korosi guna melindungi pipa dari korosi dan mengurangi kerugian-kerugian yang terjadi akibat korosi. Proteksi yang biasa digunakan untuk menghambat laju korosi, yaitu ; impressed current cathodic protection (ICCP) dan sacrificial anode cathodic protection (SACP).

Perbedaan keduanya ada beberapa hal salah satunya pada besar arus yang dihasilkan, arus padaICCP lebih besar dibandingkan denganSACP. Oleh karena itu, PT Pertamina EP Asset 2 Field Prabumulih yang berada di SKG X PBM - Cambai memilih untuk menggunakan ICCP sebagai sistem proteksi katodik pipa guna untuk memperkecil laju korosi. Selain arus yang dihasilkan besar, ICCP sangatlah cocok digunakan karena, kondisi area yang mendukung seperti jalur pipa tidak melewati jalan, tidak menyeberangi sungai dan dengan panjang pipa 10 kilometer. 
Untuk inspeksi pada sistem proteksi katodik pipa diperlukan pemantauan rutin tiap bulannya.Pengukuran yang dilakukan setiap kilometer disepanjang flowline SKG X PBM Cambai untuk mengukur potensial arus pada pipa.

\section{TEORI DASAR}

\subsection{Jalur pipa}

Dalam industri migas menggunakan beberapa fasilitas pendistribusian minyak dan gas dapat dilakukan dengan mengguakan kendaraan, dan pipa transportasi.Dari sumursumur menuju ke pengolahan berikutnya ataupun dari proses ke proses. Pendistribusian langsung menggunakan pipa sebagai sarana perpindahannya fluida.

Jalur pipa (pipeline) merupakan sarana yang banyak digunakan untuk mentransmisikan fluida pada industri minyak dan gas. Merupakan bentangan jalur pipa yang terdiri dari batangan-batangan pipa yang disambung dan berfungsi untuk mengalirkan fluida baik cair maupun gas dari satu lokasi ke lokasi yang lain. Dalam industri migas, pipa penyalur berperan besar sebagai sarana distribusi dan transportasi, baik untuk fluida (minyak dan gas) maupun fluida pendukung yang digunakan selama proses pengolahan dari sumur produksi ke fasilitas pengumpul atau ke fasilitas proses.

Sistem perpipaan untuk setiap industri tidaklah jauh berbeda, perbedaan mungkin terjadi pada kondisi khusus. Umumnya system perpipaan merupakan standar dari unit .Pabrikasi pipa dapat dilakukan pada bengkelbengkel di lapangan atau pada suatu pembuatan pipa khusus disuatu tempat lalu dikirim kelapangan baik melalui transportasi laut ataupun darat, sehingga di lapangan hanya merupakan pelaksanaan penyambungan saja.

\subsubsection{Jenis Pipa Berdasarkan Fungsinya}

Pipa memiliki bermacam-macam fungsi, secara umum fungsi utama dari pipa merupakan untuk menyalurkan ataupun menghubungkan produk yang berada didalam pipa dari satu titik ke titik yang lainnya, ada beberapa jenis pipa berdasarkan fungsinya jika dikelompokkan secara garis besar diantaranya fLowline, trunkline, dan injection line.

\section{a. Flowline}

Flowline berfungsi menghubungkan sumur migas ke stasiun pengumpul. Umumnya jenis pipa ini berdiameter antara 8 inch -28 inch . Aliran didalam pipa memiliki tekanan yang tinggi.

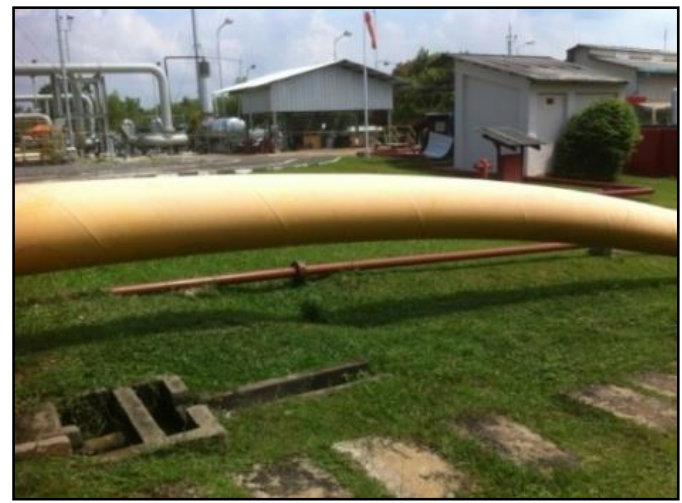

Gambar 2.1 Flowline

\section{b. TrunkLine}

Jenis pipa yang berfungsi mengalirkan fluida dari satu atau beberapa fasilitas pengumpul ke stasiun proses. Umumnya memiliki diameter yang besar dan harus memiliki pompa atau kompresor yang memadai untuk dapat mengalirkan fluida yang berada di dalamnya.

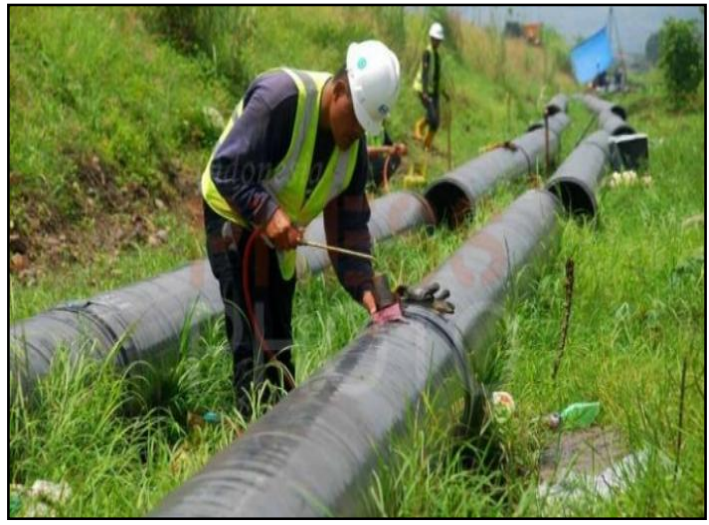

\section{Gambar 2.2 Trunkline}

\section{c. Injection line}

Injection line adalah pipeline yang mengarahkan cairan atau gas untuk mendukung aktifitas produksi (contoh: injeksi 
air atau injeksi gas, gas lift, chemical injection line)

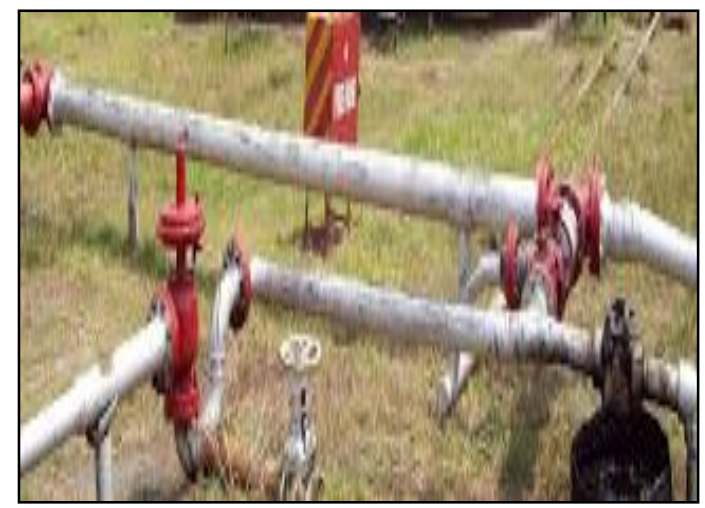

Gambar 2.3 Injection Line

\subsubsection{Berdasarkan pembuatannya}

Pipa di dalam industri pabrikasi biasanya dilakukan di bengkel pembuatan dan kemudian barulah dikirim ke tempat dimana akan dipasang. Cara ini dilakukan agar dapat mempermudah di dalam proses pemasangannya. Terdapat beberapa jenis pipa ditinjau dari proses pabrikasi atau pembuatannya, diantaranya adalah seamless pipe, straight welded pipe, dan spiral welded pipe.

a. Seamless pipe

Dalam proses pembuatannya, seamlespipe memang merupakan pipa yang dibentuk tanpa membuat sambungan sama sekali, sehingga tidak ada bagian dari pipa yang pernah terganggu atau berubah materialnya akibat panas pengelasan.

\section{b. Straight welded pipe}

Bahan utamanya merupakan lempengan panjang yang kemudian di lengkungkan $\mathrm{ke}$ arah sumbu pendeknya dengan roll pembentuk (shaperoll) sehingga membentuk pipa. Celah pertemuan kedua sisi plat tersebut kemudian di las memanjang sehingga membentuk sebuah pipa tanpa celah. Pipa ini memiliki keunggulan, yaitu pembuatanya relatif sangat mudah untuk di kontrol dan memiliki ketebalan yang seragam. c. Spiral welded pipe

Di Indonesia biasanya disebut pipa spiral, proses pembuatanya berasal dari plat yang dibentuk menjadi spiral dan kemudian disambung menggunakan las membentuk sebuah pipa.

\subsection{Kriteria pembangunan Pipeline}

Sebuah pipeline harus mempunyai beberapa kriteria yang harus dipenuhi sebagai berikut:

1. Mampu menahan tekanan akibat fluida didalamnya, untuk mengalirkan fluida dari suatu titik ke titik yang lainnya memerlukan suatu perbedaan tekanan. Tanpa adanya perbedaan tekanan tersebut fluida tidak akan dapat mengalir. Selain itu suatu proses tertentu hanya dapat terlaksana pada tekanan tertentu. Sehingga suatu pipa dalam sebuah pipeline harus mampu menahan beban akibat tekanan tersebut supaya fluida didalamnya tidak mengalami kebocoran dan mengalir keluar.

2. Mampu mengatasi gaya gesekan akibat aliran fluida, aliran fluida di dalam pipa tersebut akan mengkibatkan gaya gesekan terhadap dinding pipa akiabat adanya viskositas dari fluida dan kecepatan alirannya. Semakin besar viskositas fluida tersebut akan semakin besar gaya gesek yang ditimbulkannya, sehingga suatu pipa harus mampu menahan gesekan yang ditimbulkan fluida tersebut.

3. Mampu mengatasi momen akibat gaya berat pipa (beban statis) dan fluidadidalamnya (beban dinamik) serta akibat gaya-gaya luar. Berat pipa beserta fluida didalamnya yang tidak kecil tersebut harus mampu ditahan oleh tumpuan dan sambungan flange yang ada. Semakin panjang jarak tumpuannya maka semakin berat momen yang dihasilkan sehingga memerlukan kekuatan tumpuan dan sambungan flange yang lebih besar.

4. Mampu mengatasi beban fatigue, seperti pompa dan generator yang selalu berputar mengakibatkan beban fatigue terhadap pipeline yang berhubungan langsung terhadapnya. Dengan adanya beban fatigue dapat mengakibatkan jenis kegagalan tersendiri terhadap pipeline 
tersebut. Sehingga sebuah pipeline harus memiliki kemampuan untuk menahan beban fatigue.

5. Mampu mengatasi beban termalm, fluida didalam pipeline tersebut beroperasi pada temperatur yang berbeda-beda tergantung pada proses yang dilakukan. Temperatur yang tinggi tersebut mengakibatkan material pipa mengalami ekspansi. Sehingga suatu pipeline harus dapat menahan beban ekspansi yang diakibatkan temperatur yang tinggi tersebut.

\subsubsection{Diameter, Ketebalan dan Schedule Pipa}

Spesifikasi umum dapat dilihat pada ASTM (American Society of Testing Materials).Yang menjelaskan mengenai diameter, ketebalan serta schedule pipa. Diameter luar (outside diameter), ditetapkan sama, walaupun ketebalan (thickness) berbedauntuksetiapschedule. Diameter dalam (inside diameter), ditetapkan berbeda untuk setiap schedule. Diameter nominal adalah diameter pipa yang di pilih untuk pemasangan atau perdagangan (commodity), ketebalan dan schedule, sangatlah berhubungan, hal ini karena ketebalan pipa tergantung dari schedule pipa itu sendiri.

\subsubsection{Kelas Lokasi Pipa}

Kelas lokasi adalah area geografis disepanjang pipa yang di klasifikasikan berdasarkan jumlah dan dekatnya bangunan dan karakteristik lain yang di pertimbangkan ketika menentukan faktor desain, tekanan operasi dan metode pengujian pipa serta perlindungan yang di butuhkan. Berikut ini merupakan pembagian kelas lokasi pipa :

1. Kelas Lokasi 1

Area dikategorikan kelas lokasi 1 merupakan area yang mempunyai 10 ataukurangbangunandalam radius 1 mil. Lokas kelas 1 biasanya diperuntukkan untuk area seperti gurun, gunung, tanah pertanian dan area berpopulasi jarang.

2. Kelas Lokasi 2

Area yang dikategorikan kelas lokasi 2 merupakan area yang mempunyai jumlah bangunan antara 20 sampai 46 bangunan radius 1 mil. Kelas lokasi 2 mempunyai tingkat populasi sedang seperti daerah pinggir kota.

3. Kelas Lokasi 3

Area yang dikategorikan kelas lokasi 3 merupakan area yang memiliki jumlah bangunan lebih dari 46 bangunan pada radius 1 mil. Kelas lokasi 3 merupakan area yang sedang berkembang.

4. Kelas Lokasi 4

Area dengan kela slokasi 4 mencangkup area dimana terdapat bangunan multistori dan daerah populasi padat. Bangunan padat merupakan bangunan yang memiliki 4 lantai atau lebih.

\section{Table 2.1 Faktor Besain (F) Kelas Lokasi}

\begin{tabular}{|c|c|}
\hline Kelas Lokasi & Faktor Desain \\
\hline Lokasi 1 & 0,72 \\
\hline Lokasi 2 & 0,60 \\
\hline Lokasi 3 & 0,50 \\
\hline Lokasi 4 & 0,40 \\
\hline
\end{tabular}

Sumber : Nace Corrosion Enggineer Ref Book, thrid Edition.2002.Pierre R. Roberge, Hb.Of Corrosion Eng. Mc.Graw-Hill. 2000.

\subsection{Pemasangan Pipa}

Pekerjaan pemasangan perpipaan dapat dkelompokkan menjadi dua bagian:

1. Pemasangan pipa di atas tanah.

Pemasangan pipa diatas tanah dapat dilakukan pada rak pipa (pipe rack), diatas penyangga-penyangga pipa, diatas dudukan pipa (sleeper)

2. Di bawah tanah

Untuk pipa proses terletak dibawah permukaan dengan tujuan agar tidak terjadi yang tidak diinginkan.

\subsection{Penyambungan Pipa}

Dalam pemakaian pipa, banyak sekali diperlukan sambungan-sambungan, baik sambungan antara pipa dengan pipa maupun sambungan-sambungan antara pipa dengan peralatan yang di perlukan seperti katup (valve), instrumentasi.

Ada beberapa metode yang digunakan dalam penyambungan pipa diantaranya adalah: 1. Pengelasan

Jenis pengelasan yang dilakukan tergantung pada jenis pipa dan 
penggunaannya, misalnya pengelasan untuk bahan stainless stell menggunakan las busur, dan untuk pipa baja karbon digunakan las metal.

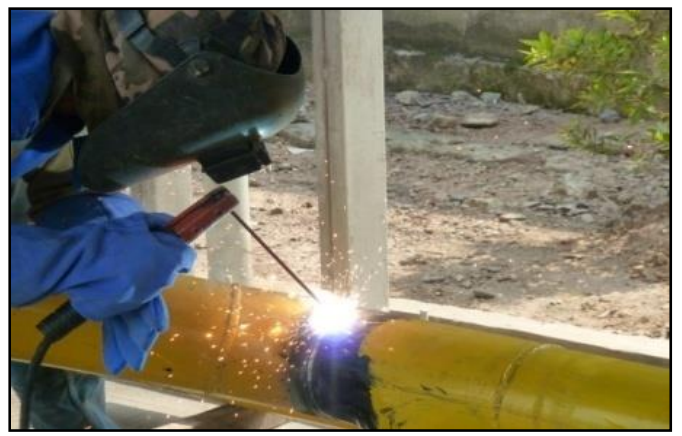

Gambar 2.5 Pengelasan Pipa

\section{Ulir (treaded)}

Penyambungan ini digunakan pada pipa bertekanan tidak terlalu tinggi. Kebocoran pada sambungan ini dapat dicegah dengan menggunakan gasket tape pipe. Umumnya pipa dengan menggunakan ulir digunakan pada pipa ukuran 2 inch kebawah.

\section{Menggunakan Flens (flange)}

Kedua ujung pipa yang akan disambung dipasang flens kemudian diikat dengan menggunakan baut.

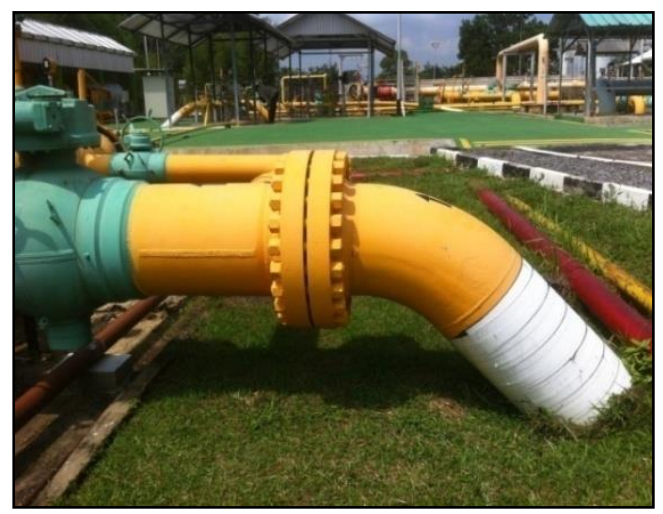

Gambar 2.7 Flange Pipe

\subsection{Tekanan Dalam Pipa}

Pipa transportasi migas memiliki batas tekanan maksimum, hal ini tergantung dari kondisi pipa yang digunakan serta pertimbangan lain seperti besaran alir-alir yang dipompakan. Maksimum tekanan dalam pipa semakin pipa tersebut digunakan, maka tekanan maksimum yang dimiliki oleh pipa tersebut akan menurun.

\subsection{Korosi}

Korosi merupakan proses elektrokimia dimana atom-atom akan bereaksi dengan zat asam dan membentuk ion-ion positif (kation). Hal ini akan menyebabkan timbulnya aliranaliran elektron dari suatu tempat ke tempat yang lain pada permukaan metal. Korosi merupakan salah satu permasalahan penting yang harus dihadapai berbagai macam sektor industri di Indonesia terutama industri perminyakan. Tidak sedikit biaya yang harus dikeluarkan sebagai akibat langsung dari masalah tersebut. Korosi hanya bisa di kendalikan atau di perlambat lajunya sehingga memperlambat proses perusakannya. Kondisi alam Indonesia yang beriklim tropis, dan dekat dengan laut adalah faktor yang dapat mempercepat proses korosi. (Siti Chodijah, FT UI, 2008)

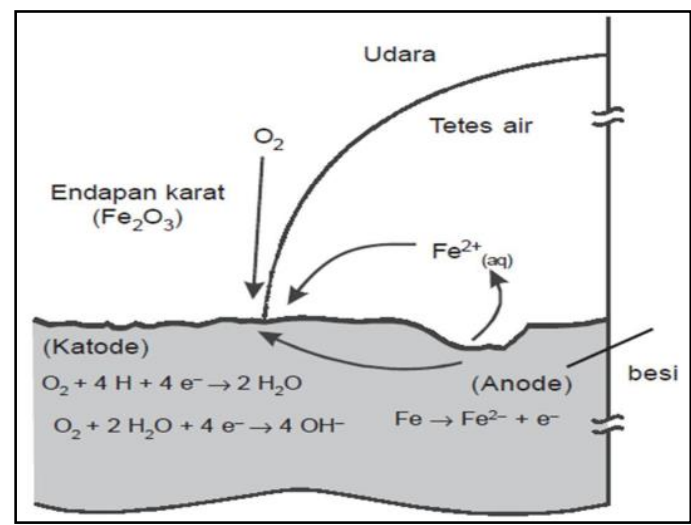

Gambar 2.8 Proses Terjadi Korosi

\subsubsection{Jenis Korosi pada Jalur Pipa}

Korosi yang terjadi pada metal dapat terbentuk dengan bebagai cara, tergantung kepada lingkungan dan jenis metalnya. Walaupun korosi banyak jenisnya, namun yang paling sering dijumpai pada pipeline sebagai berikut: 1. Korosi general atau uniform

Korosi jenis ini karena reaksi chemical dan elektro yang terjadi merata di permukaan logam, sehingga ketebalan logam akan berkurang. Alternatif pencegahanya dapat dilakukan dengan coating. 


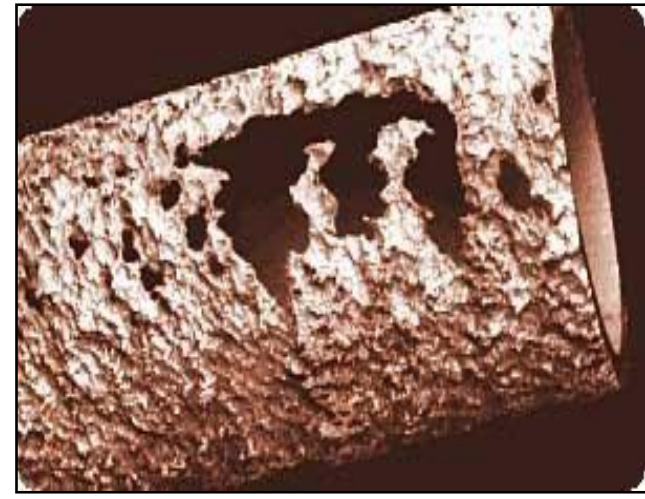

\section{Gambar 2.9 Korosi General atau Uniform}

\section{Korosi fitting}

Korosi fitting terjadi apabila suatu bagian dari metal mengalami korosi yang lebih parah (bentuknya berlubang-lubang) jika dibandingkan dengan seluruh permukaan metal tersebut. Hal ini bisa terjadi dikarenakan adanya lapisan pelindung karat yang mengalami kerusakan, sehingga terbentuk daerah anoda pada bagian pelindung karat yang rusak tersebut. Penanggulangannya adalah dengan memperbaiki atau mengganti lapisan pelindung karat yang rusak tersebut.

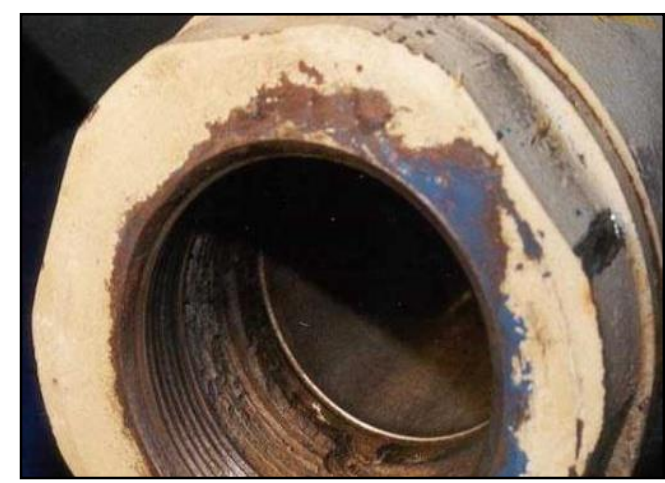

Gambar 2.10 Korosi Fitting

\section{Korosi erosion}

Korosi ini terjadi disebabkan oleh kombinasi reaksi elektrokimia dan pengaruh dari mekanikal seperti pengaliran yang deras dalam pipa, pengikisan oleh scale dan lainlainya. Korosi jenis ini banyak terjadi pada jaringan pipa gas, air atau uap. Penanggulangannya adalah dengan melapisi pipa.

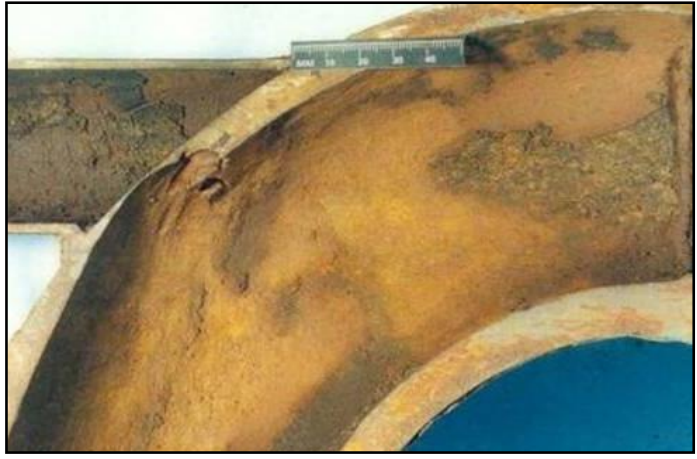

Gambar 2.11 Korosi Erosion

\section{Korosi fatigue}

Korosi ini disebabakan karena suatu metal sering mendapatkan tegangan dan berada dalam lingkungan yang korosi. Penanggulangannya adalah dengan mengurangi tegangan tersebut. Karena dengan mengurangi tegangan ini sulit dilaksanakan, maka solusinya adalah dengan menggunakan corrosion inhibitor atau logam yang tidak mudah berkarat.

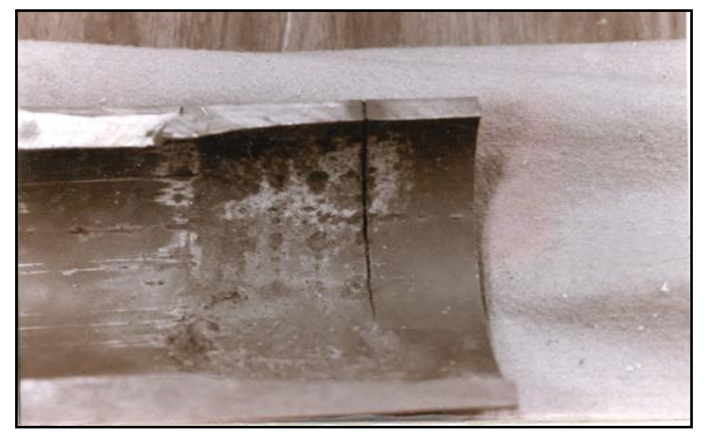

Gambar 2.12 Korosi Fatigue

5. Korosi intragranular

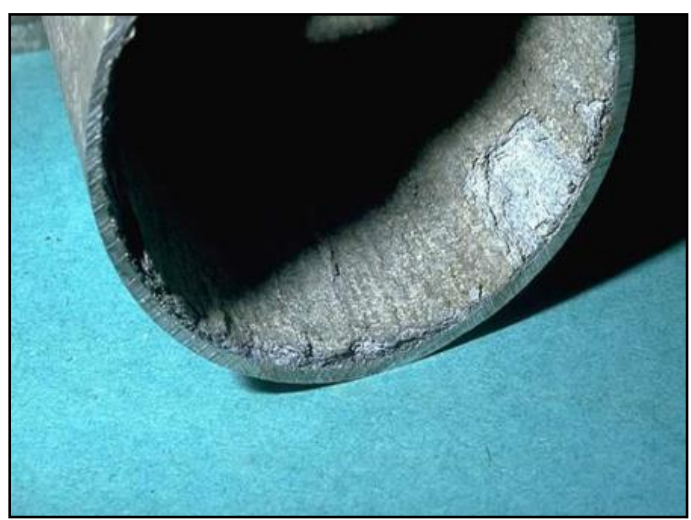

Gambar 2.13 Korosi Intragranular 
Korosi ini sering terjadi pada butiran metal (ketidak seragaman susunan batas butiran logam pada waktu pembuatannya). Ada kalanya korosi jenis ini hampir sama dengan dengan corrosion cracking, namun korosi ini terjadi bisa tanpa adanya gaya tegangan.

6. Korosi cevic

Korosi yang terjadi akibat uap air dan kotoran dari atmosfer terdapat pada celahcelah logam sehingga membentuk karat. Biasanya ditemukan pada permukaan logam yang disambung.

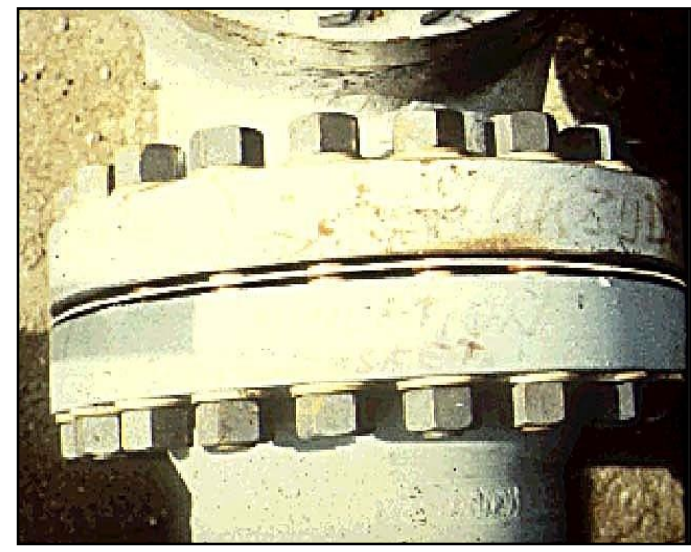

Gambar 2.14 Korosi Crevic

\section{Korosi freeting}

Penyebab terjadinya karena adanya getaran dan gesekan antara dua logam yang berdempetan. Pencegahannya adalah dengan memisahakan kedua logam atau pipa yang berdempetan tersebut atau dengan mengurangi gesekan pada kedua logam tersebut, seperti diberi pelumas.

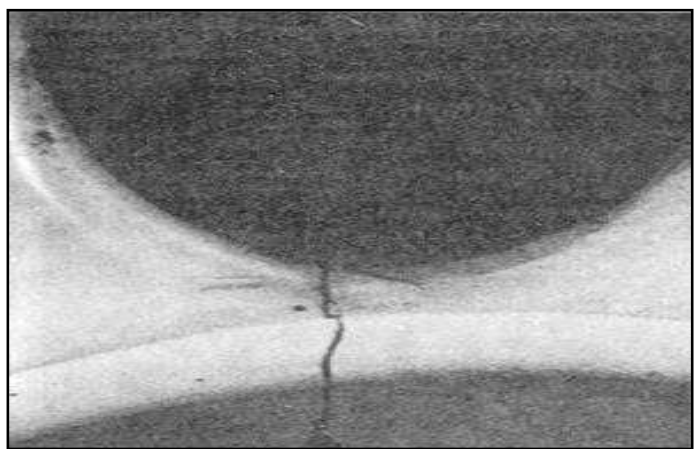

Gambar 2.15 Korosi Freeting

\subsubsection{Kerugian Korosi}

Kerugian akibat korosi dapat dibagi menjadi dua yaitu kerugian langsung dan kerugian tidak langsung.

Contoh kerugian langsung :

1. Biaya untuk mengganti material-material logam atau alat-alat yang rusak akibat korosi.

2. Biaya pengerjaan untuk penggantian material-material logam tersebut

3. Biaya untuk pengendalian korosi

4. Biaya tambahan untuk membuat kontruksi dengan logam yang lebih tebal (tahan korosi)

Contoh kerugian tidak langsung:

1. Suplai gas atau minyak hilang (shut down)

2. Citra perusahaan turun

3. Safety rendah, dan lain-lain

Kerugian akibat korosi bukan hanya untuk penggantian alat-alat proses atau konstruksi yang terkorosi, namun juga kerugian karena terhentinya pabrik sebelum waktunya, adanya kontaminasi terhadap produk, serta kehilangan bahan proses dan produk yang berharga karena kebocoran yang diakibatkan korosi. Dasar pertimbangan lain yang juga menyebabkan pentingnya penanggulangan korosi didalam industri proses perminyakan, pengaruh pada keamanan dan keselamatan kerja, serta faktor lingkungan dan korosi juga bahkan dapat sebagai penyebab kematian.

\subsubsection{Laju Korosi}

Laju korosi pada pipa merupakan kecepatan berkurangnya mutu kualitas dari pipa per tahun, sehingga dapat menimbulkan kondisi yang tidak aman di dalam transportasi migas menggunakan fasilitas pipa. Laju korosi dapat di peroleh apabila kita mengetahui spesifikasi awal pipa dan pengukuran UT wallthicknes.

Tabel 2.2 Pengelompokkan Kualitatif Laju Korosi

\begin{tabular}{|l|l|}
\hline $\begin{array}{l}\text { Corotion } \\
\text { Rate }\end{array}$ & $\begin{array}{l}\text { Severity } \\
\text { Level }\end{array}$ \\
\hline$<0,0254 \mathrm{mmpy}$ & Low \\
\hline $\begin{array}{l}0,0254 \mathrm{mmpy}-0,1245 \\
\text { mmpy }\end{array}$ & Medium \\
\hline $0,127 \mathrm{mmpy}-0,254 \mathrm{mmpy}$ & High \\
\hline
\end{tabular}




\begin{tabular}{|l|l|}
\hline $\begin{array}{l}\text { Corotion } \\
\text { Rate }\end{array}$ & $\begin{array}{l}\text { Severity } \\
\text { Level }\end{array}$ \\
\hline$>0,254 \mathrm{mmpy}$ & Severely \\
\hline
\end{tabular}

Sumber : Nace Corrosion Enggineer Ref Book, thrid Edition.2002.Pierre R. Roberge,Hb.Of Corrosion Eng. McGraw-Hill.2000.

\subsubsection{Pencegahan Korosi}

Pencegahan korosi dilakukan agar dapat meminimalisir terjadinya korosi pada jalur pipa tersebut, pencegahan korosi dapat dilakukan dengan secara pencegahan internal dan pencegahan eksternal.

1. Pencegahan korosi secara internal

a. Pemakaian bahan Kimia

Untuk memperlambat reaksi korosi digunakan bahan kimia yang disebut inhibitor corrosion yang bekerja dengan cara membentuk lapisan pelindungan pada permukaan metal. Lapisan molekul pertama yang terbentuk mempunyai ikatan yang sangat kuat yang disebut chemis option.

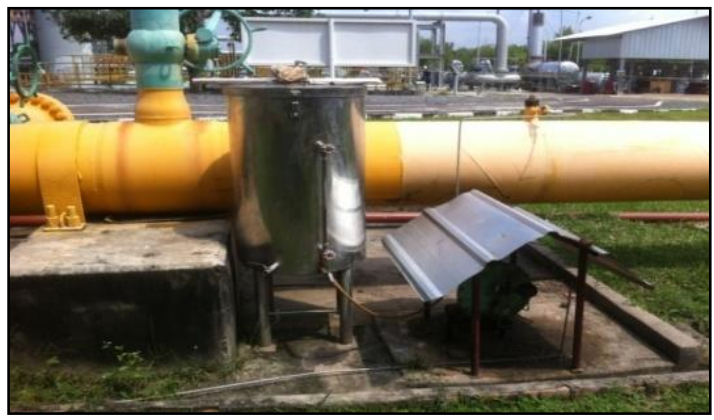

Gambar 2.16 Corrosion Inhibitor

b. Pigging

Pigging adalah metode pencegahan korosi dari dalam pipa yang membersihkan sisa air atau kondensat dalam pipa. Pipa alir (flowline) sering dibersihkan dengan pig dimasukkan kedalam pipa dan didorong oleh kekuatan aliran gas itu sendiri. Pig terbuat dari karet yang keras (rubber) yang dimasukkan melalui pipa pig launcher dan keluar pada pipa pig receive yang keduanya dipasang permanen pada suatu instalasi.

Ada bermacam-macam pig yang dipakai pada saat ini, dintaranya ada yang dilengkapi dengan roller dan pisau-pisau pembersih lengkap dengan detector untuk mengetahui sampai dimana pig tersebut sudah berjalan.

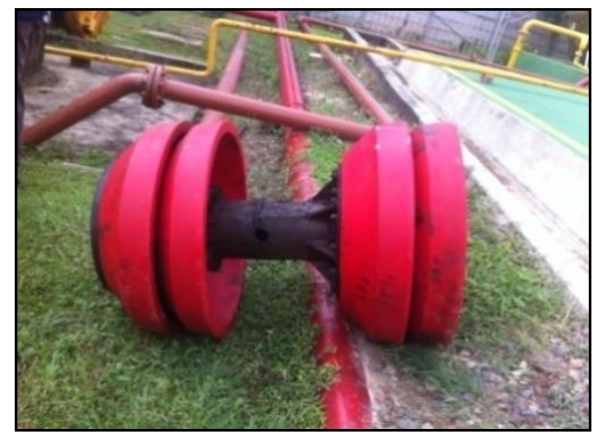

Gambar 2.17 Pig

2. Pencegahan korosi secara eksternal

a. Pengecatan (coating)

Fungsi pengecatan adalah untuk melindungi besi kontak dengan air dan udara. Cat yang mengandung timbal dan seng akan lebih melindungibesi terhadap korosi. Pengecatan harus sempurna karena jika terdapat bagian yang tidak tertutup oleh cat, maka besi akan terkorosi.

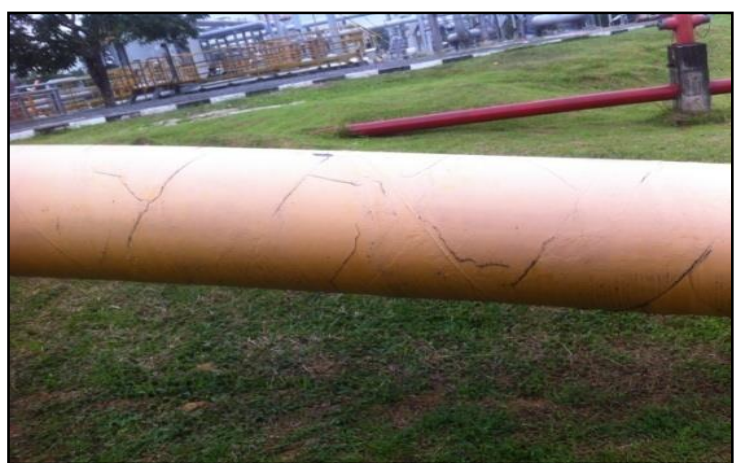

Gambar 2.18 Pengecatan (Coating)

Berdasarkan lokasi struktur yang dilindungi, maka coating terbagi beberapa jenis yaitu coating yang dapat digunakan untuk struktur bawah tanah, daerah transisi, permukaan tanah, atmospheric coating, internal coating dan lining. Untuk coating struktur bawah tanah (underground coating) yang tertanam maupun yang terendam dalam air dimana sangat sulit untuk melakukan maintenance, maka diperlukan perlindungan yang cukup. Penggunaan coating jenis cat yang tipis tidak direkomendasikan, diperlukan coating yang lebih tebal. Efek dari Handling, construction, kontak dengan batu, tekanan dari 
tanah, ketahanan material dan lain-lain yang dapat merusak coating perlu dipertimbangkan, tidak ada coating yang bisa $100 \%$ melindungi pipa, karena itu untuk perlindungan pipa terhadap korosi harus ditambah dengan sistem proteksi katodik.

Tujuan dari underground coating adalah melindungi struktur pipa dari kontak langsung dengan elektrolit dalam tanah atau dalam air. Secara umum karakteristik coating terutama untuk underground adalah sebagai berikut :

1. Mudah diaplikasikan

Underground coating harus mudah diaplikasikan baik di lapangan maupun dalam pabrik. Dan segera dapat digunakan tanpa membutuhkan waktu lama untuk menempel dengan pipa tanpa merusak coating tersebut.

2. Merekat kuat pada permukaan logam

Underground coating harus mempunyai daya rekat yang sangat baik pada permukaan pipa baja, Penggunaan primer dapat membantu daya rekat coating dengan permukaan logam.

3. tahan terhadap benturan

Underground coating harus tahan terhadap benturan tanpa menyebabkan coating retak.

4. Fleksibel

Underground coating harus cukup fleksibel atau lentur terhadap deformasi yang diakibatkan beban mekanis seperti tarikan, regangan, getaran, gesekan dan tahan terhadap perubahan temperatur.

5. Tahan terhadap tegangan tanah (soil stress)

Tegangan tanah berpengaruh terhadap coating, misalnya adalah kontraksi tanah liat pada lingkungan kering dan cuaca panas. Coating harus mampu menahan tegangan tanah tanpa terjadi kerusakan.

6. Tahan terhadap panas

Underground coating harus tahan terhadap perubahan iklim dan cuaca, coating tidak boleh meleleh atau terlepas dari pipa dikarenakan panas matahari.

\section{Tahan terhadap air}

Underground coating tidak menyerap air dan harus kedap terhadap air sehingga air tidak bisa masuk menyentuh permukaan pipa.
8. Mempunyai tahanan listrik yang tinggi

Underground coating harus bersifat isolasi dan tidak mengandung material yang mempunyai sifat penghantar listrik.

9. Stabil terhadap pengaruh secara fisik dan kimia

Tidak terjadi efek aging pada coating terhadap penetrasi molekul-molekul dariluar sehingga terjadi pelapukan atau pengerasan coating. Coating harus stabil terhadap temperature.

10. Tahan terhadap bakteri tanah coating harus tahan terhadap aktifitas bakteri tanah

11. Tahan terhadap organisme laut

Pada pipa bawah laut maka organisme laut seperti kerang, remis, barnacle dan lainlain dapat merusak coating, karena itu coating bawah laut harus tahan terhadap organisme tersebut.

b. Pelapisan (Wrapping)

Prinsip pelapisan sama dengan pengecatan yaitu untuk menlindungi agar besi tidak lagsung kontak dengan udara dan oksigen, sehingga dapat meminimalisir terjadinya korosi pada pipa transportasi tersebut.

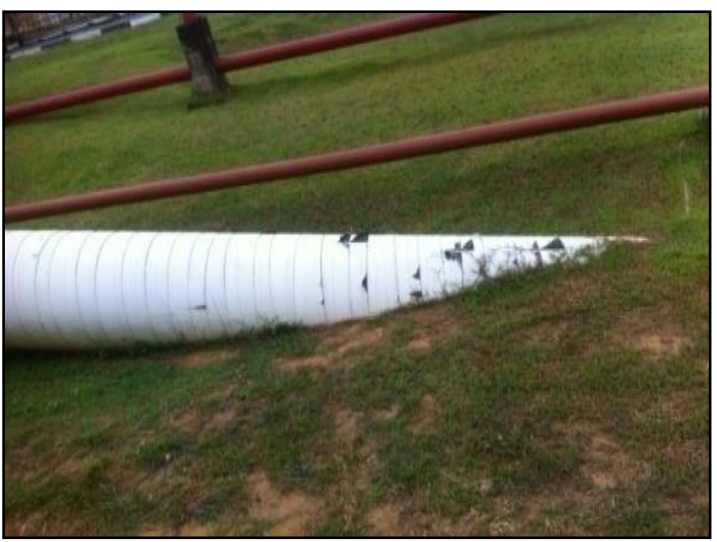

Gambar 2.19 Pelapisan (Wrapping)

c. Proteksi Katodik

Proteksi katodik ini merupakan metode yang umum digunakan untuk melindungi struktur logam dari korosi. Sistem proteksi katodik ini biasanya digunakan untuk melindungi baja, jalur pipa, tangki, tiang pancang, kapal, anjungan lepas pantai dan casing (selubung) sumur minyak di darat. 
Penggunaan pertama CP (CathodicProtection) adalah pada tahun 1852, ketika Sir Humphry Davy, salah seorang perwira AL Inggris, melekatkan sebongkah besi pada bagian luar badan kapal berlapis tembaga yang terendam air.

Besi cenderung lebih mudah mengalami korosi yang menimbulkan karat dibandingkan dengan tembaga sehingga ketika dilekatkan pada badan kapal, laju korosi pada tembaga akan menjadi turun. Ada 2 jenis sistem proteksi katodik yaitu Anoda Korban (Sacrificial Anode) dan Arus Tanding (Impressed Current). (Siti Chodijah, FT UI, 2008)

a. Anoda korban (sacrificial anode)

Perbaikan pipa bawah tanah yang terkorosi mungkin memerlukan perbaikan yang mahal biayanya. Hal ini dapat diatasi dengan teknik sacrificial anode, yaitu dengan cara menanamkan logam magnesium kemudian dihubungkan ke pipa besi melalui sebuah kawat. Logam magnesium itu akan berkarat, sedangkan besi tidak karena magnesium merupakan logam yang aktif (lebih mudah berkarat). (Siti Chodijah, FT UI, 2008)

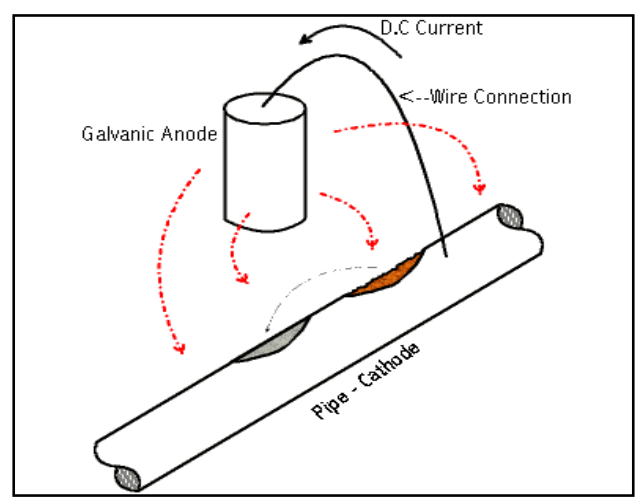

Gambar 2.20 Sistem Sacrificial Anode

Sistem anoda korban secara umum digunakan untuk melindungi struktur dimana kebutuhan arus proteksinya kecil dan resistivitas tanah rendah. Disamping itu sistem ini juga digunakan untuk keperluan dan kondisi yang lebih spesifik seperti:

1. Untuk memproteksi struktur dimana sumber listrik tidak tersedia.

2. Memproteksi struktur yang kebutuhan arusnya relatif kecil, yang jika ditinjau dari segi ekonomi akan lebih menguntungkan dibandingkan dengan sistem atus tanding.

3. Memproteksi pada daerah hotspot yang tidakdi coating, misalnya pada daerah dimana ada indikasi aktivitas korosi yang cukup tinggi.

4. Untuk mensuplemen sistem arus tanding, jika dipandang arus proteksi yang ada kurang memadai. Ini biasanya terjadi pada daerah yang resistivitas tanahnya rendah seperti daerah rawa.

5. Untuk mengurangi efek interferensi yang disebabkan oleh sistem arus tanding atau sumber arus searah lainnya.

6. Untuk memproteksi pipa yang dicoating dengan baik, sehingga kebutuhan arus proteksi relatif kecil.

b. Sistem arus tanding (impressed current)

Berbeda dengan sistem anoda korban, sumber arus pada sistem arus tanding berasal dari luar, biasanya berasal dari DC dan AC yang dilengkapi dengan penyearah arus (rectifier), dimana kutub negatif dihubungkan ke struktur yang dilindungi dan kutub positif dihubungkan keanoda. Arus mengalir dari anoda melalui elektrolit ke permukaan struktur, kemudian mengalir sepanjang struktur dan kembali ke rectifier melalui konduktor elektris. Karena struktur menerima arus dari elektrolit, maka struktur menjadi terproteksi. Keluaran (output) arus rectifier diatur untuk mengalirkan arus yang cukup sehingga dapat mencegah arus korosi yang akan meninggalkan daerah anoda pada struktur yang dilindungi. Dengan keluaran arus dari anoda ini, maka anoda tersebut terkonsumsi. Untuk itu, maka sebaiknya menggunakan bahan yang laju konsumsinya lebih rendah dari magnesium, zinc dan alumunium yang biasa dipakai untuk sistem tersebut, umumnya digunakan paduan kombinasi bahan yang khusus.

Sistem arus tanding digunakan untuk melindungi struktur yang besar atau yang membutuhkan arus proteksi yang lebih besar dan dipandang kurang ekonomis jika menggunakan anodakorban. Sistem ini dapat 
dipakai untuk melindungi struktur baik yang tidak di-coating, kondisi coating yang kurang baik maupun yang kondisi coating-nya baik. (Siti Chodijah, FT UI, 2008)

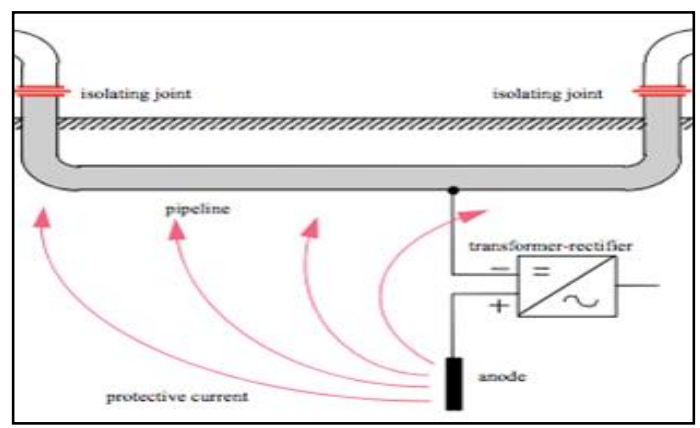

Gambar 2.21 Sistem Impressed Currrent

\section{METODOLOGI PENELITIAN}

Pelaksanaan penelitian ini dilaksanakan di PT Pertamina EP Asset 2 Field Prabumulih yang berlokasi di SKG X Prabumulih Barat, Kota Prabumulih, Sumatera Selatan. Dalam pengambilan data pada pipa transmisi PT Pertamina EP Asset 2 Field Prabumulih, ada beberapa jenis data yang diambil yaitu meliputi: data pipa (OD, jari-jari, ketebalan, dan coating), data schedule pipa dan data sistem proteksi katodik (arus, tegangan dan lain-lain).

\section{HASIL DAN PEMBAHASAN}

SKG $X$ Prabumulih Barat ini merupakan stasiun kompresor gas yang berfungsi untuk menaikkan tekanan alir gas yang rendah dari sumur menjadi tekanan alir gas yangtinggi, kemudian dijual kekonsumen dan digunakan untuk mengoperasikan komponen di SKG X. SKG X juga merupakan pusat gas PT Pertamina EP Asset 2 dari semua gas yang ada di field Pendopo, Limau, Prabumulih, kemudian dikirim ke Sumatera Selatan dan ke Jawa. SKG X merupakan titik serah gas antara PT Pertamina EP Asset 2 dengan PertaSamtan gas, Elnusa dan gas kota.

\subsection{Hasil Survey Secara Visual}

Untuk mengetahui kondisi flowline dilakukan dengan cara inspeksi visual (visualinspection). Dari hasil inspeksi visual bahwa permsalahan yang terjadi antara lain :

1) Flowline SKG X PBM - Cambai yang dibangun above ground

2) Rusaknya coating dan wrapping dibeberapa titik sepanjang jalur pipa tersebut

3) Pipa melalui wilayah perkebunan

4) Penipisan dinding pipa yang disebabkan oleh korosi

5) Korosi eksternal dipengaruhi oleh kondisi lingkungan yang dilalui oleh pipa. Kondisi lingkungan tersebut meliputi suhu udara, suhu tanah, dan tingkat keasaman tanah.

\subsection{Sistem ICCP (Impressed Current Cathodic Protection)}

Proteksi katodik (cathodic protection) adalah teknik yang digunakan untuk mengendalikan korosi pada permukaan logam dengan menjadikan permukaan logam tersebut sebagai katoda dari sel elektrokimia. Pada PT Pertamina EP Asset 2 Field Prabumulih digunakan sistem proteksi katodik arus tanding (impressed current) khususnya jalur pipa SKG X PBM - Cambai dengan panjang pipa flowline 10,1 kilometer, dimana metode ini lebih efektif digunakan dari pada menggunakan metode anoda korban (sacrificial anode). PT Pertamina EP Asset 2 Field Prabumulih Pertama kali menggunakan proteksi katodik pada tahun 1976 sampai dengan sekarang, membuktikan bahwa metode sistem proteksi katodik impressed current sangat efektif dan efisien digunakan pada jalur pipa SKG X PBM - Cambai.

Proteksi katodik impressed current dapat bekerja dengan maksimal apabila arus potensial pada pipa minimum adalah $850 \mathrm{mV}$ dan arus potensial pada pipa maksimumadalah $1.300 \mathrm{mV}$. Untuk dapat mengetahui besar arus potensial pada pipa dilakukan pengukuran test point atau test box.

\subsection{Proses Proteksi dari Impressed Current}

Pada proses proteksi impressed current, pipa yang akan diproteksi dihubungkan dengan muatan negatif sehingga sebagai katoda, sedangkan logam lain sebagai ground bed (anoda korban) dihubungkan dengan muatan positif dan berfungsi sebagai anoda. Katoda dan anoda dihubungkan dengan 
kawat penghantar melalui sumber listrik arus searah (DC) yang didapat dari transformer rectifier. Dengan cara ini arus mengalir dari anoda korban melalui elektrolit (dalam tanah) ke pipa sebagai katoda dan elektron akan mengalir dari anoda ke katoda melalui kawat penghantar listrik, sehingga pipa terhindar dari korosi.

\subsection{Komponen-komponen pada Impressed Current}

Komponen - komponen impressed current yang berperan penting dalam sistem proteksi katodik, yaitu:

\subsubsection{Power Supply}

Dalam sistem arus tanding, arus listrik searah berasal dari arus luar, umumnya menggunakan rectifier. Arus listrik dari sumber listrik tersebut dialirkan melalui kabel dan dihubungkan keanodayang dikubur atau direndam dalam elektrolit.Pada dasarnya semua bahan yang bersifat konduktor listrik dapat digunakan sebagai anoda; logam, keramik atau plastic yang konduktif dapat digunakan. Akan tetapi karena arus listrik searah yang dialirkan pada umumnya cukup besar (dalam orde sampai ratusan Ampere), maka segi teknis dan ekonomis harus diperhatikan.

\subsubsection{Ground Bed}

Ground bed adalah tempat wadah anode yang menampung korosi pada pipa disepanjang jalur pipa 24 inch SKG $X$ Prabumulih barat - Cambai dengan panjang $10,1 \mathrm{~km}$.

Beberapa jenis anoda yang awet dan berkapasitas besar telah dikembangkan oleh para ahli, untuk mencapai efisiensi yang tinggi ditinjau terutama dari kapasitas arus, umur anoda dan kemudahan pemasangan. Anoda sendiri memiliki banyak jenis, dari yang tipe boros (terkonsumsi cepat): besi atau baja; tipe semi- mulia (semi-terkonsumsi): grafit, timbal, besi-silikon, magnetit; dan tipe mulia (terkonsumsi sangat lambat): terbuat dari lapisan platina, mixed metals oxides (MMO atau MIX MEO).

Pada penggunaan anoda, PT Pertamina EP Asset 2 Field Prabumulih menggunakan mixed metals oxides dengan dilapisi titanium. PT Pertamina EP Asset 2 Field Prabumulih sendiri memilih anoda jenis MMO karena dilihat dari konsumsinya dan masa pemakaian atau umur dari pipa itu sendiri. Sehingga memilih MMO sebagai anoda yang digunakan untuk sistem proteksi katodiknya. Jalur pipa PT Pertamina EP Asset 2 Field Prabumulih khususnya pada jalur pipa 24 inch SKG X Prabumulih barat - Cambai, yaitu berumur 40 tahun. Maka dari itu, pemilihan jenis anodanya harus mengikuti umur pipa tersebut supaya lebih ekonomis (dari segi cepat atau lambatnya laju konsumsinya) dan lebih efisien dari segi penggunaan dan perawatannya.

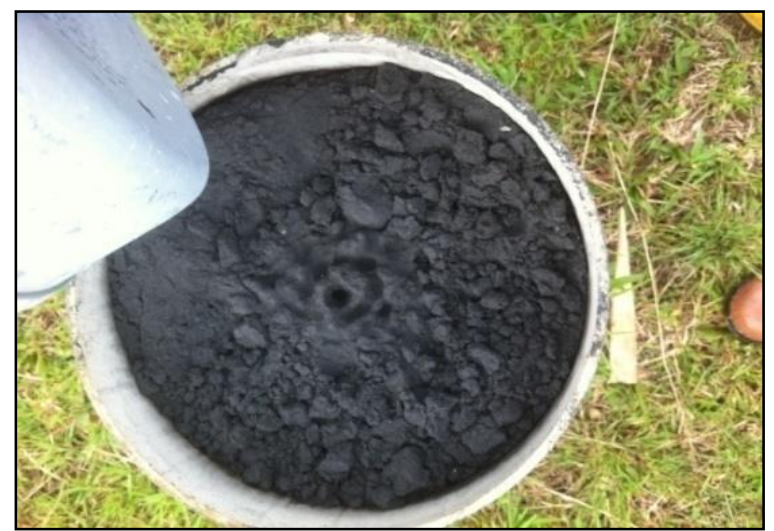

Gambar 4.1 Ground Bed

\subsubsection{Transformer Rectifier (TR)}

Transformer Rectifier merupakan sumber arus proteksi utama sistem proteksi katodik impressed current untuk jalur pipa.

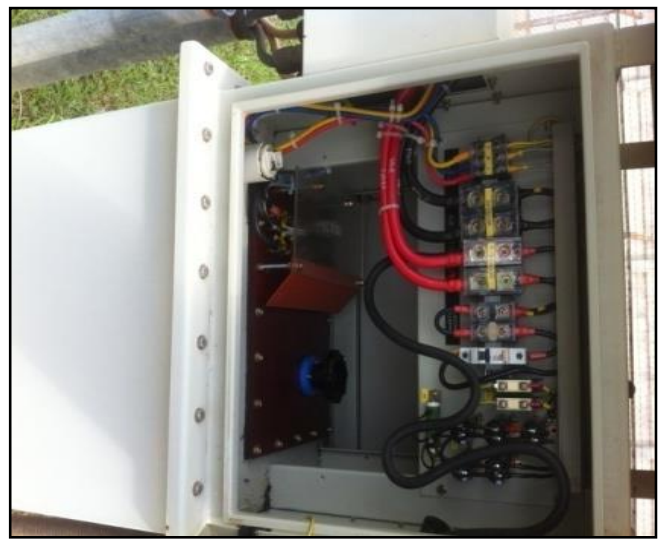

Gambar 4.2 Transformer Rectifier

Di transformer rectifier inilah arus AC diubah menjadi arus DC yang dialirkan ke 
anoda sebagai kutub positif, dan ke pipa sebagai kutub negatif sehingga dapat memproteksi pipa tersebut.

Pada transformer rectifier terdapat tap yang berfungsi untuk menaikkan tegangan, sehingga arus listrik yang dialirkan pada pipa dapat bekerja maksimal dalam pencegahan korosi.

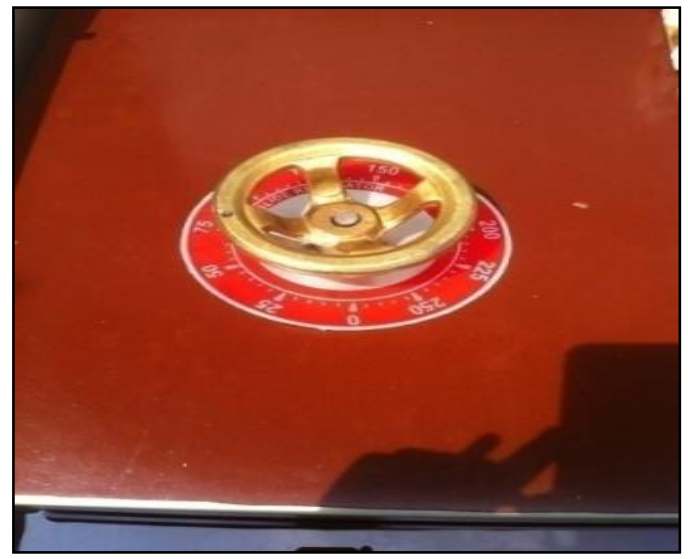

Gambar 4.3 Tap

\subsubsection{Junction Box}

Junction box adalah suatu terminal yang menghubungkan kabel kutub positif ke trafo rectifier dan kabel kutub negatif ke pipa.

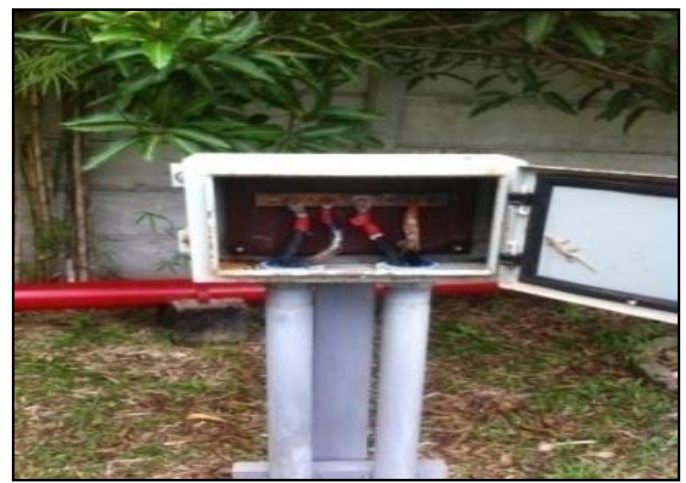

Gamabar 4.4 Junction Box

\subsubsection{Test Box}

Test box adalah tempat yang berfungsi untuk pengukuran nilai arus potensial pada pipa, pengukuran potensial juga dilakukan pada pipanya langsung namun tidak safety dan dapat merusak coating pada pipa.

\subsubsection{Multi Tester}

Multi tester adalah alat yang berfungsi untuk mengukur dan mengetahui besaran arus potensial pada testbox atau pada pipanya, dengan cara menghubungkan kabel elektroda ke pipa untuk kutub negatif dan ke elektrodanya untuk kutub positif.

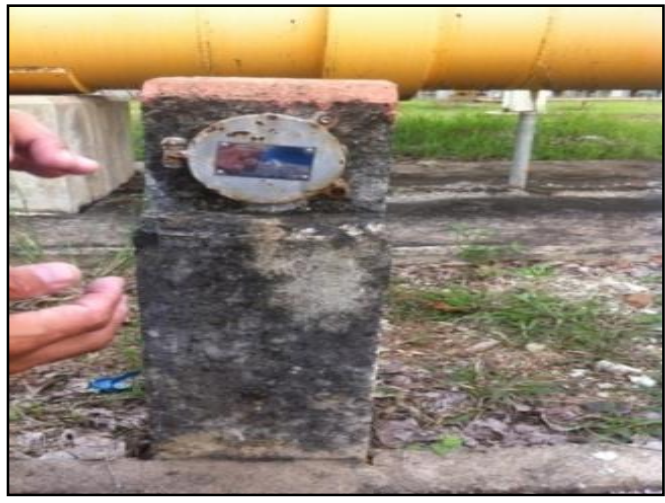

Gambar 4.5 Test Box

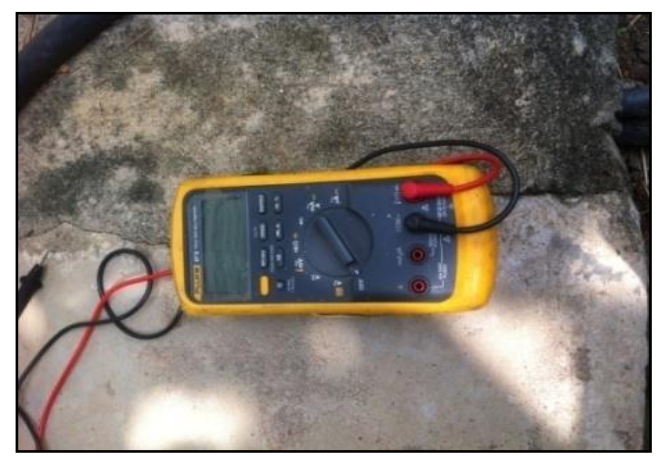

Gambar 4.6 Multi Tester

\subsubsection{Kabel Elektroda}

Kabel elektroda berfungsi sebagai penghubung. Kabel elektroda ada 2, yaitu kabel elektrodabermuatan positif yang menghubungkan multi tester pada elektroda yang ditancapkan pada tanah, dan kabel elektrodayang bermuatan negatif menghubungkan multi tester pada pipa atau test box.

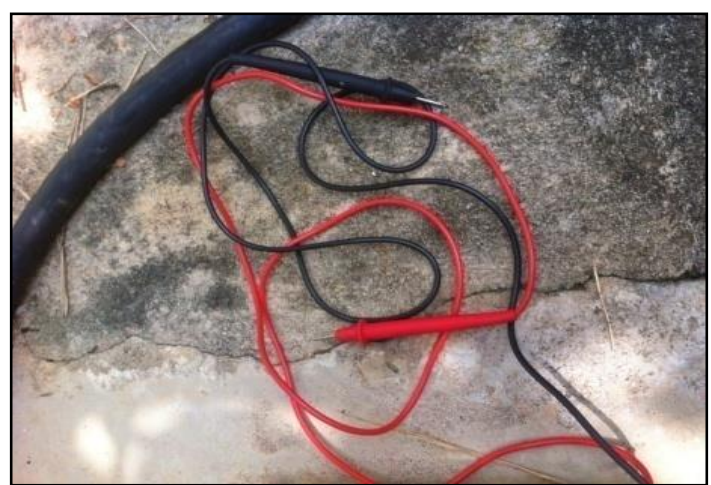

Gambar 4.7 Kabel Elektroda 


\subsubsection{Elektroda}

Elektroda berfungsi sebagai media positif yang ditancapkan ke tanah, elektroda berisi elektrolit $\mathrm{CuSO}_{4}$.

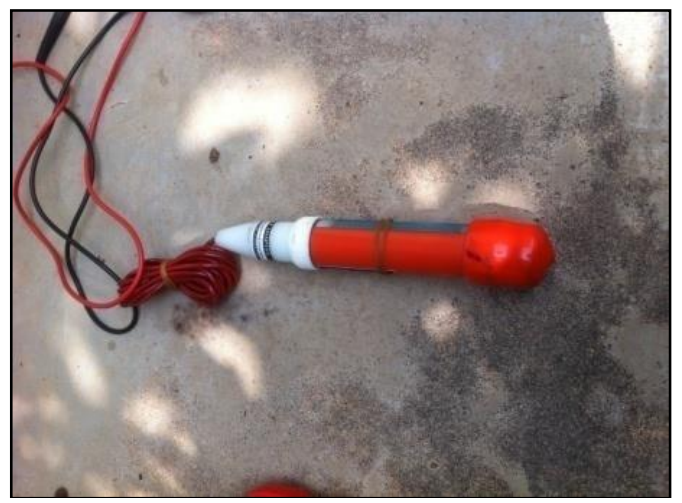

Gambar 4.8 Elektroda

\subsubsection{Tang Ampere}

Tang ampere suatu alat yang baru digunakan pada pengukuran katodik proteksi yang lebih canggih, fungsinya untuk mengetahui arus AC ampere pada trafo rectifier dan DC ampere pada pipa.

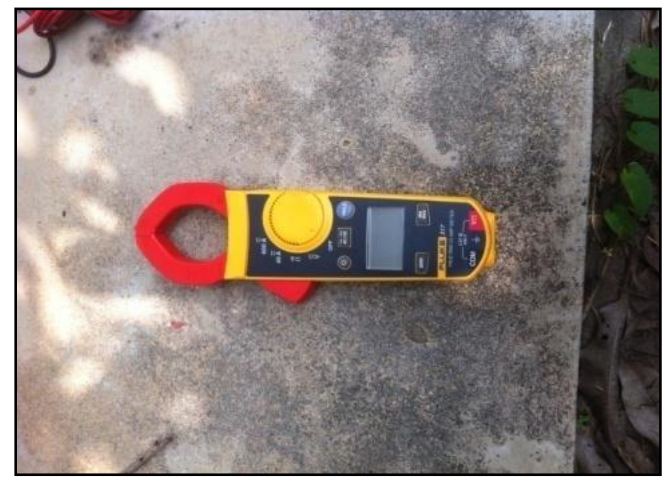

Gambar 4.9 Tang Ampere

\subsection{Pengukuran dan Pengecekan Arus Potensial pada Test Box}

Pengukuran dan pengecekan arus potensial pada setiap test box dilakukan setiap 1 bulan.Setiap test box berjarak 1 kilometer dari test box lain, dengan panjang pipa 10,1 Kilometer. Test box ini merupakan suatu kabel yang berhubungan langsung dengan pipa yang sudah diberikan arus, sehingga yang dibaca pada test box ini, yaitu tegangan. Range tegangan yang didesain pada sistem proteksi katodik ini yaitu 850 miliVolt sampai 1300 milivolt. Pengukuran test box ini menggunakan multimeter dan elektrolit $\mathrm{CuSO}_{4}$.Berikut gambar dari pengukuran dan pengecekan test box.

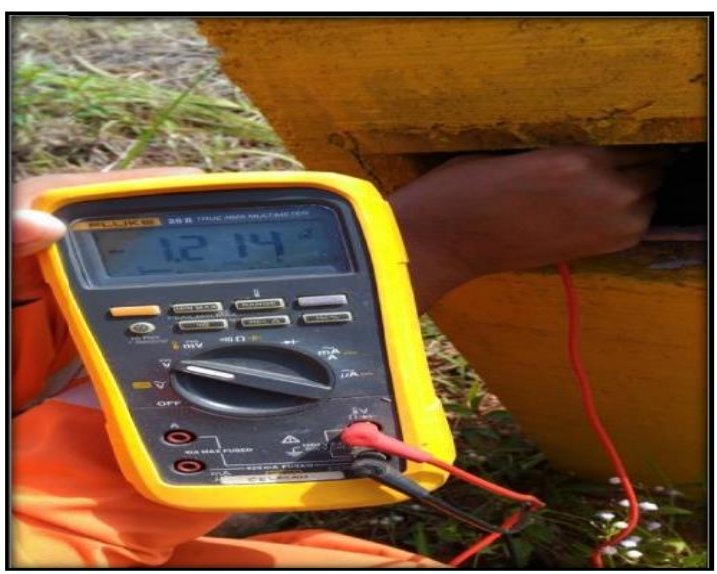

Gambar 4.10 Nilai Tegangan pada Test Box

\subsection{Kelebihan dan Kekurangan dari ICCP}

Kelebihan dari sistem arus tanding atau impressed current cathodic protection (ICCP) ini, yaitu :

1. Satu kali instalasi dapat memproteksi area yang luas, hal ini dikarenakan sistem proteksinya menggunakan arus yang didapat dari sumber arus yaitu transformer rectifier.

2. Skema bisa didesain umur penggunaannya sekitar 40 tahun, biasanya desain dari penggunaan impressed current ini didesain dengan mempertimbangkan umur pipa itu sendiri. Pada PT Pertamina sendiri. Umur dari pipanya, yaitu 40 tahun maka dari itu sistem proteksi impressed current-nya mengikuti umur pipa.

3. Bisa dikontrol secara otomatis, dari transformer rectifier kita dapat mengontrol sistem proteksinya. Apabila terjadi penurunan arus, maka dari tap-nya dapat dinaikkan sesuai yang diinginkan.

Kekurangan dari sistem arus tanding atau ICCP (impressed current cathodic protection) ini, yaitu :

1. Pemasangan sistem ICCP lebih rumit

2. Memerlukan perawatan yang lebih banyak, karena komponen peralatannya juga banyak

3. Komponen peralatannya mahal 


\subsection{Perhitungan}

\subsubsection{Proses Perhitungan korosi}

a. Ketebalan minimum

$$
\begin{aligned}
t_{\text {min }} & =\frac{\text { PxD }}{2 \times S_{4 \times \text { f Ex T }}} \\
t_{\text {min }} & =\frac{440 \text { psi } 609,6 \mathrm{~mm}}{2 \times 35000 \text { psi } 0,60 \times 1 \times 1} \\
t_{\text {min }} & =6,38 \mathrm{~mm}
\end{aligned}
$$

Ketebalan minimum yang diperbolehkan agar pipa yang digunakan aman adalah $6,38 \mathrm{~mm}$.

\section{b. Laju Korosi}

$$
\begin{aligned}
& t_{\text {loss }}=t_{\text {inst }}-t_{\text {inspeksi }} \\
& t_{\text {loss }}=9,5 \mathrm{~mm}-9,3 \mathrm{~mm} \\
& t_{\text {loss }}=0,2 \mathrm{~mm}
\end{aligned}
$$

Selama rentang waktu 3 tahun terjadi kehilangan ketebelan $0,2 \mathrm{~mm}$, dan untuk laju korosi pertahunnya dapat dihitung dengan rumus berikut ;

$$
\begin{aligned}
C_{\text {rate }} & =\frac{t_{\text {loss }}}{\Delta_{\text {time }}} \\
C_{\text {rate }} & =\frac{0,2 \mathrm{~mm}}{3 \text { year }} \\
C_{\text {rate }} & =0,0667 \mathrm{mmpy}
\end{aligned}
$$

Dapat disimpulkan bahwa laju korosi pertahunnya mencapai $0,0667 \mathrm{mmpy}$, nilai tersebut merupakan laju korosi yang sedang, maka untuk desain proteksinya harus disesuaikan untuk memperkecil laju korosi.

\section{c. Maximum Allowable Operating Pressure (MAOP)}

Maximum Allowable Operating Pressure (MAOP) merupakan tekanan maksimum yang diperoleh untuk suatu titik atau maksimum kemampuan dari suatu pipa mampu menahan tekanan dari dalam pipa tersebut, mengetahui nilai MAOP dapat menahan safety pada suatu transfortasi migas, jika kita mengetahui berapa maksimal kemampuan suatu titik pipa untuk menahan tekanan pada saat pipa beroperasi. Menghitung MAOP kita menggunakan persamaan sebagai berikut :

$$
\text { MAOP }=\frac{T_{\text {inspeksi }}(2 x F x S x E x T)}{O D}
$$

$$
\begin{aligned}
\text { MAOP } & =\frac{9,3 \mathrm{~mm}(2 \times 0,6 \times 35000 \mathrm{psi} \times 1 \times 1)}{609,6 \mathrm{~mm}} \\
\text { MAOP } & =640,7 \mathrm{psi}
\end{aligned}
$$

\section{d. Remaining life}

Setelah diketahui nilai ketebalan minimum pipa pada rentang waktu 37 tahun dan laju korosinya setiap tahunnya, maka untuk mengetahui sisa masa pakai pipa dapat dihitung dengan rumus berikut :

$$
\begin{aligned}
\mathrm{R}_{\text {life }} & =\frac{\mathrm{t}_{\text {inspeksi }}-\mathrm{t}_{\text {min }}}{\mathrm{C}_{\text {rate }}} \\
\mathrm{R}_{\text {life }} & =\frac{9.3 \mathrm{~mm}-6,38 \mathrm{~mm}}{0,0667 \mathrm{mmpy}} \\
\mathrm{R}_{\text {life }} & =43,7 \text { tahun }
\end{aligned}
$$

Dari perhitungan sisa masa pakai didapat bahwa sisa masa pakai pipa umurnya masih mampu bertahan lebih dari 40 tahun, karena pada umumnya desain pipa pada PT Pertamina EP Asset 2 Field Prabumulih bertahan sampai umur pipa 40 tahun.

\subsubsection{Proses Perhitungan Proteksi katodik}

Dari perhitungan laju korosi yang diketahui pertahunnya mencapai $0,0667 \mathrm{mmpy}$ dan sisa umur pipa tinggal 43,7 tahun lagi, maka untuk pencegahannya bisa menggunakan katodik proteksi. Oleh karena itu, PT Pertamina EP Asset 2 memilih untuk menggunakan proteksi katodik impressed current yang dapat memperkecil laju korosi dan memperpanjang umur pipa.

a. Luas Area yang akan diproteksi

$$
\begin{aligned}
& A=\pi \times \text { OD } \times L \\
& A=3,14 \times 0,609 \mathrm{~m} \times 10.100 \mathrm{~m} \\
& A=19,33 \mathrm{~m}^{2}
\end{aligned}
$$

Pada pengukuran luas area yang akan diproteksi ,memiliki diameter pipa 0,609 m. Tota lluas area yang akan terproteksi adalah sebesar 19,33 $\mathrm{m}^{2}$ atau setara dengan 0,01933 $\mathrm{km}^{2}$.

b. Total arus yang diperlukan

$$
\begin{aligned}
& \mathrm{CD}_{0}=\mathrm{CD}_{30}+\mathrm{CD}_{>30}\left(\times \frac{\mathrm{T}_{0}-30}{\mathrm{~T}_{>30}}\right) \\
& \mathrm{CDo}=20 \mathrm{~mA} / \mathrm{m}^{2}+\left(5 \times \frac{32,22^{\circ} \mathrm{C}-30}{10}\right) \\
& \mathrm{CD}_{0}=21,11 \mathrm{~mA} / \mathrm{m}^{2} \\
& \mathrm{I}=\mathrm{CDo} \times \mathrm{CB} \times \mathrm{A} \times(1-\mathrm{SF}) \\
& \mathrm{I}=21,11 \mathrm{~mA} / \mathrm{m}^{2} \times 0,01 \times 19,33 \mathrm{~m}^{2}
\end{aligned}
$$


$\mathrm{I}=4,08 \times(1-0,25)$

$I=3,06 \mathrm{~A}$

Arus adalah media yang sangat diperlukan pada sistem proteksi katodik menggunakan ICCP, dari arus tersebut kita dapat mencegah terjadinya laju korosi pada pipa gas. Total arus yang diperlukan untuk memberikan arus proteksi pada pipa yaitu 3,06 ampere, sehingga spesifikasi transformer rectifier disetel dengan arus 3,06 ampere atau dilebihkan menjadi 3,366 ampere (nilainya ditambahkan safety factor sebesar 10\%).

c. Densitas arus anoda

$$
\begin{aligned}
& \log 10 \text { ID }=3,3-\log 10 Y \\
& I D=10^{(3,3-\log 40)} \\
& \text { ID }=49,88 \mathrm{~A} / \mathrm{m}^{2}
\end{aligned}
$$

Densitas dari arus anoda sendiri yaitu sebesar 49,88 A/m $\mathrm{m}^{2}$ yang didapat berdasarkan perhitungan yang melibatkan umur pipa.

d. Luas permukaan Anoda

$$
\begin{aligned}
& S=\pi \times \text { DA } \times \text { LA } \\
& S=3,14 \times 0,0254 \mathrm{~m} \times 1 \mathrm{~m} \\
& S=0,079 \mathrm{~m}^{2}
\end{aligned}
$$

Anoda yang digunakan pada sistem ICCP ini yaitu mixed metal oxides (MMO) dengan diameter 1 inchi atau setarad engan 0.0254 meter, bahan ini sangatlah tahan lama jika dibandingkan dengan bahan-bahan yang lain. Dari perhitungan, diketahui bahwa luas permukaan anoda, yaitu $0,079 \mathrm{~m}^{2}$

e. Arus Keluaran Maksimal

$$
\begin{aligned}
& \text { Io }=\mathrm{S} \times \text { ID } \\
& \text { Io }=0,079 \mathrm{~m}^{2} \times 49,88 \mathrm{~A} / \mathrm{m}^{2} \\
& \text { Io }=3,94 \mathrm{~A}
\end{aligned}
$$

Arus keluaran maksimal yang diberikan oleh anoda yaitu sebesar 3,94 ampere yang disambungkan pada kabel ke junction box dan disalurkan ke transformer rectifier. Arus anoda inilah yang akan diubah oleh transformer rectifier dari arus AC menjadi arus DC yang disalurkan nantinya kepipa gas untuk diproteksi.

f. Jumlah anoda yang diperlukan

$$
\begin{aligned}
& \mathrm{Q}_{\min }=\frac{\mathrm{It}}{\mathrm{IO}} \\
& \mathrm{Q}_{\text {min }}=\frac{3,06 \mathrm{~A}}{3,94 \mathrm{~A}} \\
& \mathrm{Q}_{\text {min }}=0,73 \mathrm{pcs} \approx 1 \mathrm{pcs}
\end{aligned}
$$

Dari perhitungan arus di atas, dapat dihitung jumlah anoda yang diperlukan untuk konsumsi proteksi katodik. Jumlah keseluruhan anoda yang dibutuhkan adalah 1 pcs yang akan memproteksi jalur pipa gas seluas $19,33 \mathrm{~m}^{2}$

\subsection{ParameterKeberhasilan}

Parameter-parameter keberhasilan dalam pelaksanaan sistem proteksi katodik ini yaitu:

1. Tegangan yang dihasilkan tidak melebihi range yang ditentukan, yaitu 850 sampai $1.300 \mathrm{mV}$

2. Pipa terlindungi dari korosi dengan proteksi katodik ICCP

\subsection{Rangkuman Hasil Pengolahan dan Analisa Data}

Tabel 3.1 Hasil Pengolahan dan Analisa

Data

\begin{tabular}{|c|l|c|}
\hline No. & Parameter & Hasil \\
\hline 1 & $\begin{array}{l}\text { Ketebalan Minimum (T } \\
\text { minimum) }\end{array}$ & $6,38 \mathrm{~mm}$ \\
\hline 2 & $\begin{array}{l}\text { Kehilangan Ketebalan } \\
\text { (T Loss) }\end{array}$ & $0,2 \mathrm{~mm}$ \\
\hline 3 & $\begin{array}{l}\text { Laju Korosi (Corrosion } \\
\text { rate) }\end{array}$ & $\begin{array}{l}0,0667 \\
\mathrm{mmpy}\end{array}$ \\
\hline 4 & $\begin{array}{l}\text { Sisa Masa Pakai } \\
\text { (Remaining life) }\end{array}$ & $\begin{array}{c}43,7 \\
\text { tahun }\end{array}$ \\
\hline 5 & $\begin{array}{l}\text { Luas area yang } \\
\text { diproteksi }\end{array}$ & $19,33 \mathrm{~m}^{2}$ \\
\hline 6 & $\begin{array}{l}\text { Total Arus yang } \\
\text { Diperlukan }\end{array}$ & $3,06 \mathrm{~A}$ \\
\hline 7 & $\begin{array}{l}\text { Desitas Arus Anoda } \\
49,88 \\
\mathrm{~A} / \mathrm{m}^{2}\end{array}$ \\
\hline 8 & $\begin{array}{l}\text { Luas Permukaan Anoda } \\
0,079 \mathrm{~m}^{2}\end{array}$ \\
\hline 9 & $\begin{array}{l}\text { Arus Keluaran } \\
\text { Maksimal }\end{array}$ & $3,94 \mathrm{~A}$ \\
\hline 10 & $\begin{array}{l}\text { Jumlah Anoda Korban } \\
\text { yang diperlukan }\end{array}$ & $1 \mathrm{pcs}^{2}$ \\
\hline
\end{tabular}

Dari hasil pengolahan dan analisa data dapat diketahui bahwa ketebalan minimum pipa yang diizinkan adalah $6,38 \mathrm{~mm}$, serta pipa tersebut mengalami kehilangan ketebalan sebesar 0,2 $\mathrm{mm}$ dalam rentang waktu 3 tahun yang diakibatkan karena laju korosi per tahunnya sebesar 0,0667 mmpy dan sisa umur pipa yang masih dapat digunakan sampai 43,7 tahun. 
Luas area yang diproteksi sepanjang 10,1 km pada jalur pipa 24 inch memiliki luas area $19,33 \mathrm{~m}^{2}$ dengan total arus yang diperlukan 3,06 A dan memiliki densitas arus anoda 49,88 $\mathrm{A} / \mathrm{m}^{2}$. Pada luas permukaan anoda $0,079 \mathrm{~m}^{2}$ hanya mengeluarkan arus maksimal sebesar 3,94 A dan dengan jumlah anoda korban yang diperlukan 1 pcs.

\section{KESIMPULAN DAN SARAN}

\subsection{Kesimpulan}

Dari pembahasan tersebut, maka kesimpulan dari penelitian ini, yaitu :

1. Laju korosi pada pipa sebesar $0,0667 \mathrm{~mm}$ per tahunnya yang termasuk dalam tingkatan korosi sedang, dan sisa umur pipa hanya bisa digunakan 43,7 tahun lagi

2. Prinsip kerja proteksi katodik ICCP yaitu arus DC berasal dari transformer rectifier, pipa sebagai katoda dan anoda korban sebagai anoda. arus mengalir dari anoda korban melalui elektrolit (dalam tanah) ke pipa sebagai katoda dan elektron akan mengalir dari anoda ke katoda melalui kawat penghantar listrik, sehingga pipa terhindar dari korosi.

3. Proteksi katodik ICCP memiliki kelebihan yang mampu memproteksi area yang luas, bisa didesain mengikuti umur pipa dan potensial pada pipa sepanjang 10,1 km dapat dikontrol dari transformer rectifier dengan menaikkan nilai tap, dan kekurangan proteksi katodik ICCP yaitu Pemasangan sistem ICCP lebih rumit, memerlukan perawatan yang lebih banyak, karena komponen peralatannya juga banyak, dan komponen peralatannya mahal

4. Pemilihan jenis anodanya harus mengikuti umur pipa tersebut supaya lebih ekonomis (dari segi cepat atau lambatnya laju konsumsinya) dan lebih efisien (dari segi penggunaan dan perawatannya). Dalam perhitungan jumlah anoda, jalur pipa 24 inch SKG $X$ Prabumulih - Cambai menggunakan 1 pcs anoda karbon dan total arus yang diperlukan 3,06 A untuk memproteksi pipa seluas $19,33 \mathrm{~m}^{2}$

\section{DAFTAR PUSTAKA}

Ahmad, Zaki. 2006. Principles Of Corrosion Engineering and Corrosion Control. Boston: Elsevier Science. pdf

Baeckmann,W.Von.

Schwenk,W,.Prinz,W,.dkk.1997. Theoryand Practice of Electrochemical Protection Processes. USA: Elsevier Science. pdf

Nace Corrosion Enggineer Ref Book, Thrid Edition.2002. Pierre R. Roberge, Hb. Of Corrosion Eng. Mc.Graw-Hill. 2000. pdf

Chodijah, Siti. 2008. Efektifitas Penggunaan Pelapis. FT 
P-ISSN: 2089-5925 E-ISSN: 2621-9328

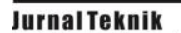

Jurnal Teknik Patra Akademika

PAFA

Arademika

Volume 10 No. 01 Juli 2019 